\title{
A maradványhallás megörzésének lehetőségei cochlearis implantáció során Nucleus CI532 Slim Modiolar elektródasorral
}

\author{
Nagy Roland ${ }^{1 *}$. Jarabin János András dr. ${ }^{1 *}$. Dimák Balázs ${ }^{1}$ \\ Perényi Ádám dr. ${ }^{1}$. Tóth Ferenc dr. ${ }^{1}$ - Szúts Viktória dr. ${ }^{2,3}$ \\ Jóri József $\mathrm{dr}^{1}{ }^{1}$ - Kiss József Géza $\mathrm{dr}^{1 * *}$ - Rovó László dr. ${ }^{1 \text { * * }}$
}

Szegedi Tudományegyetem, 'Általános Orvostudományi Kar, Fül-Orr-Gégészeti és Fej-Nyaksebészeti Klinika,

${ }^{2}$ Mérnöki Kar, Élelmiszermérnöki Intézet, Szeged

${ }^{3}$ Magyar Tudományos Akadémia, Szegedi Biológiai Kutató Központ, Növénybiológiai Intézet, Szeged

\begin{abstract}
A hallássérült betegek rehabilitációjában alkalmazott cochlearis implantáció során a residualis hallás posztoperatív megőrzése és a hallási teljesítmény maximalizálása az elektródaprofil implantációjakor kialakult trauma minimalizálásától függ. Ennek megvalósításához minimálinvazív módszerek, továbbá vékonyabb, atraumatikus elektródasorok alkalmazására volt szüikség. Célunk a posztoperatív akusztikai hallásmaradvány-megőrzés lehetőségének audiológiai nyomon követése volt. Betegünk veleszületett halláscsökkenése miatt gyermekkora óta hagyományos, légvezetéses hallásjavító készüléket viselt mindkét fülén. A cochlearis implantációt 6 hónappal megelőzően halláscsökkenésében mindkét oldalon kifejezett progressziót mértünk, ezért cochlearis implantátum beültetése mellett döntöttünk. A beteg a mútétet megelőzően mindkét fülén rendelkezett residualis hallással, ezért Cochlear® Nucleus CI532 Slim Modiolar implantátumot alkalmaztunk. A minimálisan invazív mútétet a beteg jobb fülén végeztük el kerekablakbehatoláson keresztül. A preoperatív hallásküszöbhöz (átlag $85 \mathrm{dBHL}$ ) viszonyítva a 4. posztoperatív héten $0,25-1,0$ kHz között 5-10 dBHL, míg 2,0-4,0 kHz-en 20-25 dBHL mértékú iniciális hallásküszöbromlást tapasztaltunk. A 6. hónapban mért hallásküszöb az $1 \mathrm{kHz}$ feletti tartományban további kisfokú progressziót mutatott, ugyanakkor a 12. hónapban a hallásküszöb javult, a 4. héten kapott eredményekkel megegyezett. A cochlearis implantáció residualis hallásra gyakorolt hatásait több tanulmány is vizsgálta, melyekben számos sebészi és technikai tényező kulcsszerepét meghatározták. A CI532 Slim Modiolar eletródaprofil modiolushoz közeli elhelyezkedése várhatóan kisebb endocochlearis hidrodinamikai terhelést jelent, mindemellett lehetővé teszi, hogy a ganglion spirale szomszédos idegelemeit alacsonyabb áramintenzitással, kisebb felületen ingerelhessük, ami neuroprotektív hatású lehet. Az akusztikai hallásmaradvány cochlearis implantáció kapcsán történő megôrzése javítja a beteg beszédértését és hanglokalizációs képességét, különösen nehezített körülmények között. A residualis hallás hosszú távú megőrzése kiemelkedő fontosságúnak bizonyulhat továbbá a későbbi regeneratív eljárások, gyógyszeres kezelések megvalósíthatósága kapcsán is.
\end{abstract}

Orv Hetil. 2018; 159(41): 1680-1688.

Kulcsszavak: cochlearis implantátum, CI532 Slim Modiolar elektróda, maradványhallás-megőrzés, minimálinvazív sebészet

\section{Possibilities for residual hearing preservation with Nucleus CI532 Slim Modiolar electrode array}

\section{Case report}

During the rehabilitation of hearing-impaired patients, the preservation of residual acoustic hearing following cochlear implantation by minimizing the implantation trauma allows for improved hearing performance. To achieve this, minimally invasive, soft surgery methods and thinner, atraumatic electrodes were required. In our present study, we

*N. R. és *J. J. A. megosztott első szerzőként, * *R. L. és * *K. J. G. megosztott utolsó szerzőként jegyzik a kéziratot. 
reported a case where Cochlear ${ }^{\circledR}$ Nucleus CI532 Slim Modiolar electrode was implanted in a patient with residual hearing. Our aim was to study the possible preservation of postoperative acoustic residual hearing by audiological monitoring. Since childhood, due to her congenital hearing loss, she has been wearing a conventional, airborne hearing correction device on both ears. Six months before cochlear implantation, we measured the progression on both sides of the hearing loss, so we decided to perform cochlear implantation. The patient had residual hearing on both ears prior to surgery thus the Cochlear ${ }^{\circledR}$ Nucleus CI532 Slim Modiolar Implant was used. The minimally invasive surgery was performed on the patient's right ear through the round window approach. Compared to the preoperative hearing threshold (average $85 \mathrm{dBHL}$ ) in the 4 th postoperative week, an initial hearing threshold progression of 20-25 dBHL was observed between 0.25 and $1.0 \mathrm{kHz}$, while of $5-10 \mathrm{dBHL}$ between $2.0-4.0 \mathrm{kHz}$. Hearing threshold measured in the 6th month showed a slight progression in the range above $1 \mathrm{kHz}$, but improved by the 12th month, to the results achieved at the 4th week. The effects of cochlear implantation on residual hearing have been studied in numerous studies, in which several key surgical and technical factors have been identified. Nucleus CI532 is a Slim Modiolar electrode profile that is close to the modiolus, so it is expected to have a lower endocochlear hydrodynamic load since it lies in the covering of the osseus spiral lamina, thus less influencing the dynamics of the basilar membrane. However, the perimodiolar location of the electrode array allows the adjacent nerve elements of the spiral ganglion to be stimulated with a lower electrical intensity and a reduced surface that may be neuroprotective. Preservation of acoustic residual hearing following cochlear implantation improves the patient's speech perception and the sound localization skills, particularly in difficult circumstances. Long-term residual hearing preservation may also be of great importance in the subsequent feasibility for regenerative procedures and drug treatments.

Keywords: cochlear implant, CI532 Slim Modiolar electrode, residual hearing preservation, soft surgery

Nagy R, Jarabin JA, Dimák B, Perényi Á, Tóth F, Szűts V, Jóri J, Kiss JG, Rovó L. [Possibilities for residual hearing preservation with Nucleus CI532 Slim Modiolar electrode array. Case report]. Orv Hetil. 2018; 159(41): 16801688.

(Beérkezett: 2018. március 1.; elfogadva: 2018. április 5.)

\section{Rövidítések}

ASSR $=$ (auditory steady-state response) auditoros steady-state válasz; $\mathrm{CI}=$ cochlearis implantátum; $\mathrm{CT}=($ computed tomography) számítógépes tomográfia; BERA $=$ (brainstem evoked response audiometry) agytörzsi kiváltott potenciál vizsgálat; DPOAE $=($ distortion product otoacoustic emission $)$ disztorziós otoakusztikus emisszió; EAS = (electric-acoustic stimulation) elektroakusztikus stimuláció

A legutóbbi években csaknem az összes súlyossági fokú és típusú halláscsökkenés rehabilitálhatóvá vált valamely implantálható hallásjavító rendszer alkalmazásával [1-3]. A cochlearis implantátumok (CI) évtizedek óta jó funkcionális eredménnyel biztosítják a különböző hátterú cochlearis károsodásból eredő, súlyos fokú halláscsökkenések rehabilitációját mind gyermekek, mind felnőttek esetében [4]. A CI egy mútéti úton, részben beültetett hallásjavító eszköz, mely közvetlenül a csiga lumenébe vezetett, szőrsejtprotézisként múködő elektródasoron át hozza ingerületbe a hallóideg még múködő perifériás sejtjeit. A cochlearis implantátumok múködési elve a következő: a külső beszédprocesszor a környezet hangjait elektromos jelekké alakítja át, melyeket az adótekercs az intakt bőr alatt elhelyezkedő belső implantátumegységhez továbbít. Az elektromos impulzusok ezt követően a belső elektronikához csatlakozó elektródasoron keresztül közvetlenül a ganglion spirale sejtekhez, majd a cent-

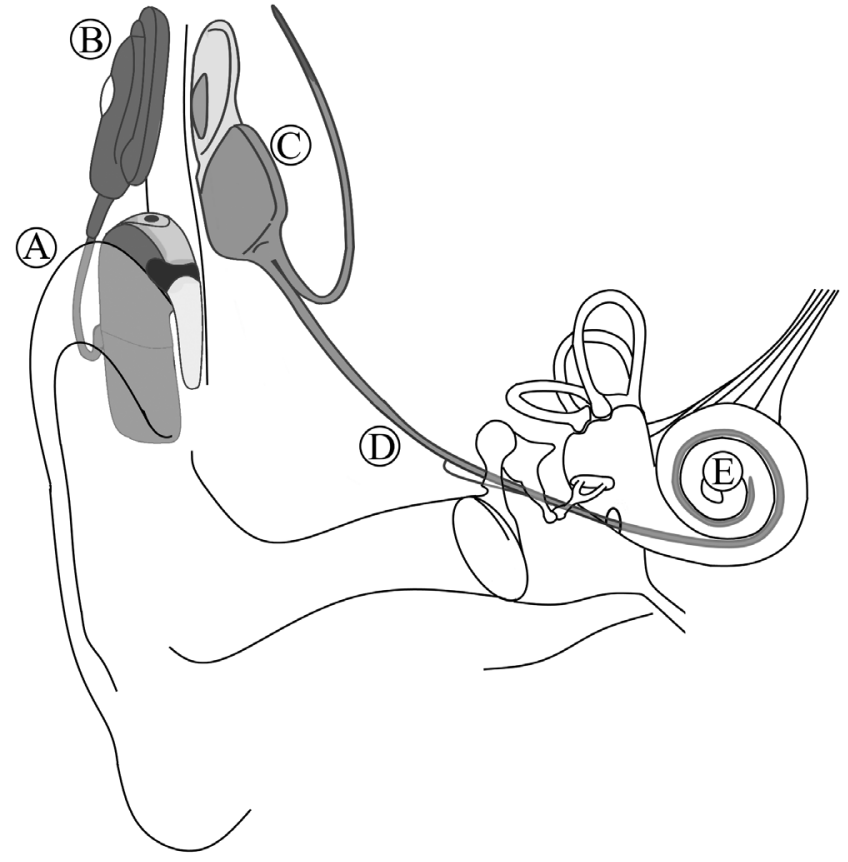

1. ábra $\quad$ A cochlearis implantátum sematikus felépítése és múködése. A külső beszédprocesszor (A) a környezet hangjait elektromos jelekké alakítja át, melyeket az adótekercs (B) az intakt bőr alatt elhelyezkedő belső implantátumegységhez (C) továbbít. Az elektromos impulzusok ezt követően a belső elektronikához csatlakozó elektródasoron (D) keresztül közvetlenül a ganglion spirale sejtekhez (E), majd a centrális hallópályán keresztül a hallókéreghez jutnak 


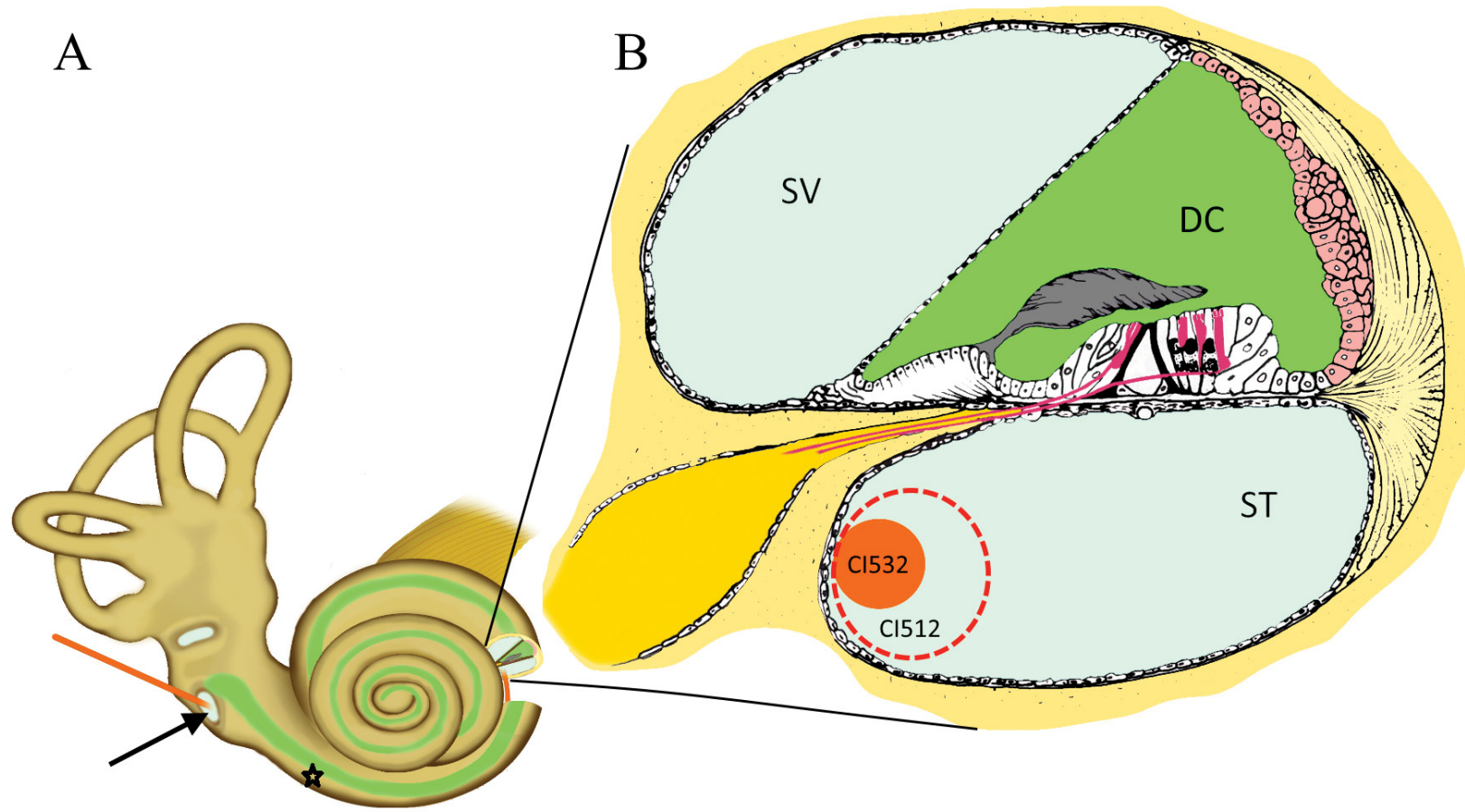

2. ábra

A Cochlear ${ }^{\circledR}$ Nucleus CI532 Slim Modiolar elektródaprofil endocochlearis elhelyezkedése. A cochlea megnyitásának leggyakoribb sebészi kapui

(A) A sémás ábra a labyrinthus szerkezetét ábrázolja, melyen jól látható a fenestra rotundán (fekete nyíl) át bevezetett elektródasor (narancsszínű). Alternatív sebészi behatolásként, a cochleostoma furatának helyét az ábrán fekete csillag jelöli. Az ábra jobb oldalán kinagyított átmetszeti kép a csiga mikroszkópos vázlati szerkezetét, az implantáció sikeressége szempontjából nélkülözhetetlen folyadéktereit ábrázolja (ST - scala tympani; SV - scala vestibuli; DC - ductus cochlearis)

(B) Látható a scala tympaniba vezetett elektródasor intracochlearis elhelyezkedése két, eltérő elektródaprofil fizikai paramétereinek illusztrációjával. A CI532-es (narancsszínú, tömör átmetszetú) elektródaprofil körülbelül 60\%-os relatív keresztmetszet-csökkenése, következményes intracochlearispozíció-változása szembetúnő a korábbi, CI512-es (narancsszínú, szaggatott körvonalú) elektródaprofilhoz képest

rális hallópályán keresztül a hallókéreghez jutnak $(1 / A-$ Eábra).

Megjelenésük óta a CI-k jelentős technikai fejlődésen mentek keresztül, ami időről időre a mütéti technikák adaptációját tette szükségessé. A kezdetektől fogva jelen volt az a törekvés, hogy a beteg esetleges residualis hallását a mütétet követően is megőrizzük [5]. Ezen koncepció különösen előtérbe került minden olyan esetben, amikor a beteg mélyhang-hallása még hagyományos hallókészülékkel is rehabilitálható volt, ugyanakkor a beszédértés az egyidejûleg jelen lévő, súlyos fokú, közép- és magashang-vesztés miatt akusztikai erősítés mellett is csaknem lehetetlen volt. Ez vezetett az elektroakusztikus stimuláció (EAS) elvén múködő implantátumrendszerek megjelenéséhez, melyek egyszerre alkalmaznak hagyományos, akusztikai erósítést, továbbá implantált, elektromos stimulációt [6]. Az előbbi a mély hangok tartományában nyújt erősítést, míg az utóbbi a magasabb hangok területén biztosít kellő stimulációt, így optimalizálva a beteg beszédértését.

A residualis hallás posztoperatív megörzése ösztönözte az egyre vékonyabb, atraumatikus elektródasorok megalkotását is $[5,7]$. A hallási teljesítmény maximalizálása ugyanis a beillesztési trauma minimalizálásától függ [8]. Cochlearis implantáció során károsodhatnak az endocochlearis struktúrák, melyek azonnali vagy akár késői posztoperatív residualishallás-romlás forrásai lehetnek [9-11]. Az elektródasor bevezetése során esetlegesen kialakuló belsőfül-trauma az eredete alapján, sebészi szempontból, két csoportba sorolható. Ezek közül az első az elektródasornak a scala tympaniba történő célzott bevezetése [12]. A legelterjedtebb sebészi technikák ezt vagy a kerekablak-membránon át (úgynevezett „round window approach"), vagy egy úgynevezett cochleostomán, azaz a cochlea basalis kanyarulatának mesterséges furatán át valósítják meg [10] (2. ábra). A második jelentősebb csoportot az elektródasor minimális traumát okozó bevezetése képezi. Ebben szintén számos tényezőnek lehet meghatározó szerepe, mint például: (1) az elektróda bevezetése során keletkező közvetlen trauma; (2) az implantáció kapcsán a perilympha folyadéktérben kialakuló nyomáshullám hatása; (3) a fúró által okozott vibráció, hangártalom, esetleg hőtrauma; (4) perilymphavesztés; (5) a belső fül folyadéktereinek homeosztázisában létrejövő változások; endolymphaticus hydrops kialakulása; (6) a csiga lumenének késői fibroticus, csontos átalakulása $[13,14]$. Az elektródasor hossza és keresztmetszete szintén korlátozhatja a posztoperatívan elérhető residualis hallás megőrzését [15]. A közép- és a belső fül átfogó preoperatív radiológiai elemzése segíthet mind a mütéti behatolás megtervezésében, mind az elektródaprofil kiválasztásában [16-18]. 
EAS-t alkalmazva a magashang-tartományban károsodott szórsejtek területét, azaz a basalis régiót sok esetben egy rövid elektródasor bevezetésével fedik le, mellyel megkímélhető az apicalis cochlearis régiók szerkezete, múködése. Ez esetben a kihívást a residualis hallás hoszszabb távú megörzése jelenti [19]. Ha ugyanis a mélyhang-hallásban progresszió következik be, az eredetileg optimális hosszúságú elektróda, fizikai lefedettség hiányában, már nem lesz képes pótolni a cochlea ezen régiójának funkcióját. A progresszió hátterében kiváltó okként szerepelhet késői endocochlearis fibrosis vagy csontszövetképződés is [20]. Az ebben a helyzetben felmerülő teljes belsőegység-csere, hosszabb elektródasor bevezetése ennek kapcsán akár fizikai akadályba is ütközhet. Elzáródás hiányában ugyanakkor akár több egymást követő implantáció szükségessé válhat, követve a beteg hallásának folyamatos rosszabbodását, ezzel nyilvánvaló sebészi, altatási terhet róva a betegre. Mindemellett számos finanszírozási kérdés is felmerülhet.

A cél tehát egy atraumatikus elektródasor kifejlesztése volt, mely a residualis hallás maximális megőrzése mellett képes az elektromos hallás hosszú távú biztosítására. A cochlea teljes hosszában bevezetve az elektródasort kezdetben az EAS részeként üzemelhet, majd egy esetlegesen bekövetkező mélyhanghallás-vesztés esetén, az apicalisan elhelyezkedő elektródákat aktiválva, csupán az implantátum programozásának módosításával biztosítható újra a teljes cochlea elektromos hallás lefedése. A folyamat lényege tehát egy hibrid, akusztikus és elektromos rendszerről tisztán elektromos rendszerre történő áttérés a beültetett elektródasor cseréje nélkül.

Az előbbi feltételeknek véleményünk szerint megfeleló elektródasor (Cochlear ${ }^{\circledR}$ Nucleus „CI532 Slim Modiolar”) 2015 novemberében „closed-market release” keretében a Szegedi Tudományegyetem Fül-Orr-Gégészeti és Fej-Nyaksebészeti Klinikáján került beültetésre elsőként a világon (operatőr: Prof. Dr. Rovó László tanszékvezető egyetemi tanár).
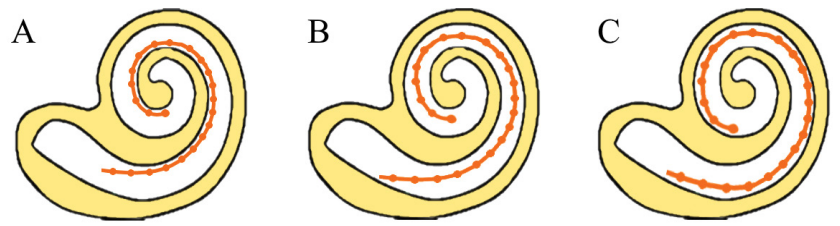

3. ábra

Az elektródaprofilok csoportosítása a modiolustól való távolságuk alapján. Az elektródaprofilok modiolustól való távolságuk alapján (A) perimodiolaris, (B) mid-scala, (C) ,lateral-wall” típusba sorolhatók. A jelen cikk tárgyát képező Nucleus CI532-es elektróda a perimodiolaris csoport tagja

Klinikánkon ez idáig 89 esetben ( 69 beteg) ültettünk be CI532-es elektródasort, melyek közül 40 fö esetében mértünk preoperatív residualis hallást. A homogén betegcsoportok adatainak részletes feldolgozása jelenleg folyamatban van.

Jelen tanulmányunkban egy olyan esetról számolunk be, amelyben Cochlear ${ }^{\circledR}$ Nucleus CI532 Slim Modiolar elektródát ültettünk be residualis hallással rendelkező betegnek. Vizsgálatainkkal arra kerestük a választ, hogy rövid vagy akár hosszú távon is megőrizhető marad-e az akusztikai hallás.

\section{Anyag és módszer}

\section{Nucleus CI532 Slim Modiolar elektródaprofil}

Az elektródaprofilokat a modiolustól való távolságuk alapján perimodiolaris, „mid-scala”, illetve "lateral-wall” kategóriákba sorolhatjuk (3. ábra) [21]. A Nucleus CI532-es elektródasor jelenleg a világ egyik legkisebb átmérőjü perimodiolaris pozíciójú elektródaprofilja. Basalisan $0,5 \mathrm{~mm}$, míg apicalisan $0,3 \mathrm{~mm}$ átmérőjü, ezzel mintegy 60\%-ban kisebb térfogatú, mint a gyártó szintén perimodiolaris elhelyezkedésú, előző generációs elektródaprofilja, az úgynevezett Nucleus Contour Advance (4. ábra) [22]. Különleges, rugalmas háromdimenziós (3D-s) konformációjának köszönhetően lehe-
A
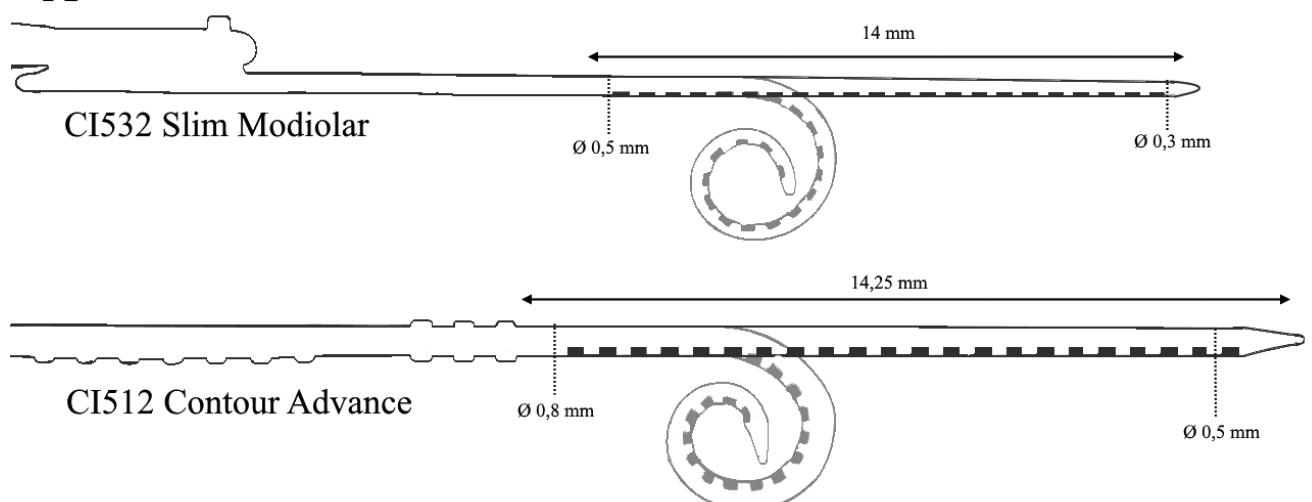

B
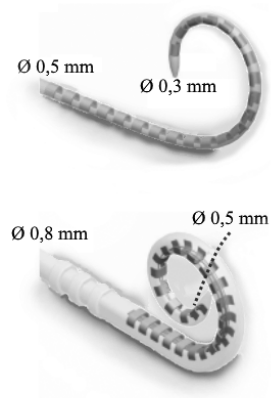

4. ábra

Perimodiolaris elektródasorok összehasonlítása. Az ábrán a Nucleus CI532 vékony, perimodiolaris elektródaprofil méretei láthatók az előző, úgynevezett Contour Advance elektródaprofilhoz képest. A Nucleus CI532-es elektródasor jelenleg a világ legkisebb átmérőjü perimodiolaris pozíciójú elektródaprofilja. Basalisan 0,5 $\mathrm{mm}$, míg apicalisan $0,3 \mathrm{~mm}$ átmérőjű, ezzel mintegy $60 \%$-ban kisebb térfogatú, mint a szintén perimodiolaris elhelyezkedésű, előző generációs elektródaprofil, az úgynevezett Nucleus Contour Advance CI512 
tővé teszi, hogy az elektródák a lamina spiralis ossea eredése alatt helyezkedjenek el, így biztosítva, hogy a stimulációs pontok a ganglion spirale sejtjeinek közelébe kerüljenek (2/B ábra). Atraumatikus kialakítása biztosítja az endocochlearis finomstruktúrák megőrzését [23]. Egyedülálló beillesztési mechanizmussal rendelkezik, amely a sebész számára lehetővé teszi, hogy kiválaszthassa a legmegfelelőbb megközelítést a cochlea anatómiájának függvényében. A biztonság érdekében az elektróda újratölthető vezetőeszközzel rendelkezik, mely szignifikáns mértékben növeli az elektróda optimális helyzetbe kerülésének esélyét [21].

\section{Minimálisan invazív sebészi technika}

A residualis hallás cochlearis implantáció során történő megőrzésének szándéka vezetett az úgynevezett „soft surgery”, azaz minimálisan invazív mütéti eljárások megjelenéséhez. Ezek alapvetően meghatározzák a cochlea megnyitásának és az endocochlearis manipulációknak minden olyan elemét, amely makro- és mikroszerkezeti károsodások által negatívan befolyásolhatja a posztoperatívan elérhető hallásteljesítményt (direkt trauma és/ vagy különböző anyagok bekerülése a cochleába stb.). A minimálisan invazív cochlearis implantációs eljáás tehát nem konkrét mútéti típus, hanem inkább olyan szabályok összessége, melyeket követve egyre tökéletesebb funkciómegőrzés lehetséges. A fogalmat és a föbb szempontokat elsőként Lehnhardt közölte 1993-ban [24], ami számos később megjelent publikáció alapját jelentette [25]. A residualis hallás megőrzésének szándéka legújabban az EAS-rendszerekkel történő hallásrehabilitáció során merül fel [26-28].

Minimálinvazív technikát alkalmazva egyaránt választhatunk kerek ablakon, kiterjesztett kerekablak-behatoláson vagy cochleostomán át történő elektródabevezetést [11]. A csont szükséges mértékü elfúrásához minden esetben $1 \mathrm{~mm}$ átmérőjü gyémántfúrót használunk lassú fordulatszámon, ezzel elkerülve a fúrás során keletkező hang- és hőártalmat $[13,14]$. Az endosteum megnyitása előtt, annak felszínére szteroidtartalmú oldatot vagy nátrium-hialuronát-tartalmú készítményt helyezhetünk. Az endosteum megnyitásához mikrotüt vagy -horgot, továbbá különböző lézereket használhatunk. A belső fül megnyitását követően fokozottan ügyelnünk kell arra, hogy elszívás közben nehogy perilymphavesztést okozzunk. A scala tympani csupán a lehető legrövidebb ideig lehet nyitva, ugyanis azon mint behatolási kapun át primeren vagy az elektródához tapadva szekunder módon csontpor, vér vagy egyéb anyag juthat a belső fülbe, mely számos direkt és/vagy másodlagos károsodás forrása lehet, s ez végső soron a posztoperatív residualis hallás csökkenéséhez, elvesztéséhez vezethet. Bevezetése előtt, a Nucleus CI532-es elektródaszálat az implantátumhoz tervezett speciális vezetősínbe vissza kell húzni. Ez elősegíti az optimális implantációs szög meghatározását, megtartását. Az elektródaszál bevezetése a lehető legki- sebb erő kifejtése mellett kell, hogy történjen. Minden érzékelhető ellenállás a basilaris membrán, a lateralis scala tympani fal vagy a stria vascularis kontaktusát, következményes sérülését jelezheti. Az elektródaszál bevezetését elősegítheti felszínének szteroidos oldattal vagy nátrium-hialuronáttal történő bevonása. Amint az elektróda a megfelelő hosszúságban bevezetésre került - amit markergyürúk jeleznek -, a kerek ablakot vagy a cochleostomát autológ szövettel (például fascia, izomszövet) lezárjuk, megelőzve a további perilymphavesztést [25].

Az implantátumtestet és a referenciaelektródát a gyártó által kiadott templát segítségével a bőr alatt kialakított zsebbe helyezzük.

\section{Betegadatok}

Nőbetegünk 1987-ben született. Veleszületett halláscsökkenése miatt gyermekkora óta hagyományos, légvezetéses hallásjavító készüléket viselt mindkét fülén. A cochlearis implantációt 6 hónappal megelőzően halláscsökkenésében mindkét oldalon kifejezett progressziót mértünk, így már készülékeinek viselése mellett sem volt kielégítő beszédmegértési képessége. Mütéti alkalmasságát részletes audiológiai és radiológiai tesztekkel bíráltuk el. Ezt követően az implantációt a beteg 30. életévében végeztük el általános anesztéziában. Mivel a beteg a mütétet megelőzően mindkét fülén rendelkezett residualis hallással, vékony perimodiolaris elektródaprofil (CI532 Slim Modiolar implantátum) alkalmazása mellett döntöttünk. A mútétet a beteg jobb fülén végeztük el a fentebb részletezett minimálisan invazív sebészi technikát alkalmazva kerek ablakon keresztül.

\section{Eredmények}

\section{Preoperatín hallásvizsgálatok}

A preoperatív hallásdiagnosztika teljes körű szubjektív és objektív tesztekból állt. Az elvégzett tisztahang-küszöbaudiometria a beszédfrekvenciákon $(0,25-1,0 \mathrm{kHz})$ átlagosan 85 dBHL hallásküszöböt igazolt $(5 / A$ ábra), míg a beszédaudiometria az audiométer méréshatáráig nem volt vizsgálható.

Az objektív teszteket normális középfül-ventiláció mellett végeztük (normál A típusú timpanogram mindkét oldalon). A disztorziós otoakusztikus emisszió (DPOAE) mérésével egyik oldalon sem volt regisztrálható külsőszőrsejt-aktivitás, ami sensorineuralis halláscsökkenés esetében belsőfül-eredetet igazol. Agytörzsi kiváltott potenciál vizsgálattal (BERA) nagy intenzitás mellett még éppen regisztrálható, kis amplitúdójú, ugyanakkor normál atenciájú, reprodukálható válaszokat regisztráltunk, ami szintén a Corti-szerv-eredet mellett szól. Az agytörzsi szakaszon neuralis érintettségre (úgynevezett retrocochlearis laesióra) utaló jeleket nem láttunk. Auditoros steady-state válaszok (ASSRs) vizsgálata során az 

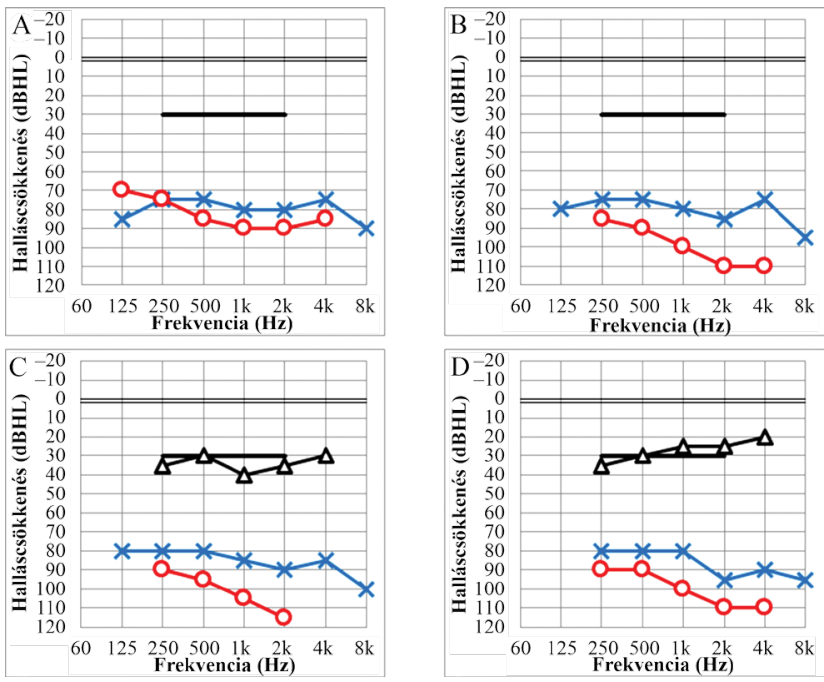

5. ábra

Pre- és posztoperatív tisztahang-küszöbaudiometriai eredmé nyek. Az implantációt a jobb fülön végeztük el (piros görbék) az ellenoldali hallást a kék görbék jelzik. A preoperatív tisztahang-küszöbaudiometria a beszédfrekvenciákon $(0,25-1,0$ $\mathrm{kHz}$ ) átlagosan $85 \mathrm{dBHL}$ hallásküszöböt igazolt $(\mathrm{A})$. A negyedik posztoperatív héten a beszédfrekvencia-tartományt tekintve 0,25-1,0 kHz között 5-10 dBHL, míg 2,0-4,0 kHz-en 20-25 dBHL mértékú iniciális hallásküszöbromlást tapasztaltunk (B) A 6. hónapban mért hallásküszöb $1 \mathrm{kHz}$ felett ismét progressziót mutatott (C), ugyanakkor a posztoperatív 12 . hónapban, javulást követően, a 4. héten kapott eredményekkel megegyezó hallásküszöbértékeket mértünk (D). A 6. hónapban elvégzett szabad hangteres hallásküszöb-vizsgálat a jobb fülön viselt cochlearis implantátummal közel a szociális hallásküszöbnek megfelelő hallást igazolt, átlag 35-40 dBHL küszöbszinttel. A posztoperatív 12. hónapban mért szabad hangteres hallásküszöb további javulást mutatott, átlag 25-30 dBHL-nek bizonyult

Jelölések: $-\mathrm{X}-=$ bal oldali légvezetéses hallásküszöb; $-\mathrm{O}-=$ jobb oldali légvezetéses hallásküszöb; $-\Delta-=$ CI-vel mért hallásküszöb szabad hangtérben

objektív hallásküszöböt mindkét oldalon nagy-súlyos fokúnak becsültük (6. ábra).

Eredményeink alapján tehát a beteg bizonyos mértékú residualis hallással rendelkezett ugyan, ez azonban a hagyományos légvezetéses erősítéssel nem lett volna kellő mértékben rehabilitálható. Az objektív tesztek a nervus cochlearis retrolabyrinther károsodását nem vetették fel, melyet a preoperatívan elvégzett nagy felbontású piramiscsont-CT-vizsgálat szintén kizárt. Belsőfül-fejlődési rendellenesség nem ábrázolódott.

Mivel a beteg a cochlearis implantáció audiológiai és radiológiai indikációs kritériumainak megfelelt, mútétet javasoltunk.

\section{Posztoperatín hallásvizsgálatok}

Az első ellenőrző tisztahang-küszöbaudiometriai vizsgálatunkra a negyedik posztoperatív héten került sor $(5 / B$ $a ́ b r a)$. A beszédfrekvencia-tartományt tekintve $0,25-1,0$ kHz között 5-10 dBHL, míg 2,0-4,0 kHz-en 20-25 dBHL mértékú iniciális hallásküszöbromlást tapasztaltunk. Ezt követően a posztoperatív hatodik és tizenket- tedik hónapban újabb kontroll-hallásvizsgálatot végeztünk. A 6. hónapban mért hallásküszöb $\mathrm{l} \mathrm{kHz}$ felett ismét progressziót mutatott $(5 / C$ ábra), ugyanakkor a posztoperatív 12 . hónapban $(5 / D a ́ b r a)$, javulást követően, a 4. héten kapott eredményekkel megegyező hallásküszöbértékeket mértünk. A posztoperatív teszteket tisztán akusztikus ingerrel, a cochlearis implantátum kikapcsolása mellett végeztük el.

\section{Elektrofiziológia}

A Nucleus CI532 egy 22 csatornából álló vékony, perimodiolaris elhelyezkedésû́ elektródaprofillal rendelkező implantátum. A posztoperatív hallásvizsgálatokkal egy időben elvégzett elektródánkénti impedanciamérések számos ingadozást mutatva, a 10-22. elektródatartományban már a 6. hónapban, míg az 1-9. elektródákon a 12. hónapban válnak relatíve stabillá, kiegyenlítetté (7. ábra), ami az elektródasor megfelelő integrációjára, a belsőfül-homeosztáziásnak a rendezettségére utalhat.

\section{Megbeszélés}

Az akusztikai residualis hallás cochlearis implantáció kapcsán történő megőrzése javítja a posztoperatívan elérhető periodicitást és spektrális felbontást, aminek köszönhetően javul a beteg beszédértése és hanglokalizációs képessége, különösen nehezített körülmények között, ezért kiemelkedő annak megörzése [29-35].

A cochlearis implantáció residualis hallásra gyakorolt azonnali hatásait több tanulmány is vizsgálta, melyekben számos sebészi és technikai tényező kulcsszerepét meghatározták [10, 36, 37]. Hasonló vizsgálatok kutatják a mikrofülsebészeti beavatkozások labyrinthfunkciókra gyakorolt hatásait [38]. Az implantációt követő időszakban ugyanakkor számolnunk kell késői komplikációkkal is, úgymint endocochlearis kötő- vagy csontszövetképződéssel, mely másodlagosan a residualis akusztikai hallás romlásához, elvesztéséhez vezethet [20]. Erre a legnagyobb valószínűség a kiterjesztett kerekablak-feltáráskor („extended round window approach”) mutatkozik, melynek során az endosteum károsodása vált ki új szöveti proliferációt. A legcsekélyebb a károsodás kialakulásának valószínúsége minimálinvazív kerekablak-behatolás során [10]. A cochlea hidrodinamikai rendszerének károsodása ugyanakkor létrejöhet egy, az alaphártya mozgását korlátozó elektródasor jelenléte miatt is. Ekkor a membrana basilaris eltéró maximummal és helyen tér ki a különböző hangokra, így a haladóhullám terjedését befolyásoló elektródasor a mély frekvenciákért felelős apicalis régió elemeit is károsíthatja, úgynevezett cochlearis vezetéses halláscsökkenést okozva $[39,40]$. Az új típusú, vékony átmérőjü, modiolushoz közeli elhelyezkedésü elektródasorok várhatóan kisebb hidrodinamikai terhelést jelentenek, hiszen a lamina spiralis ossea takarásában, az alatt helyezkednek el, a membrana basilarist nem érintik (2. ábra). Az elektródasor perimodiolaris elhelyezke- 


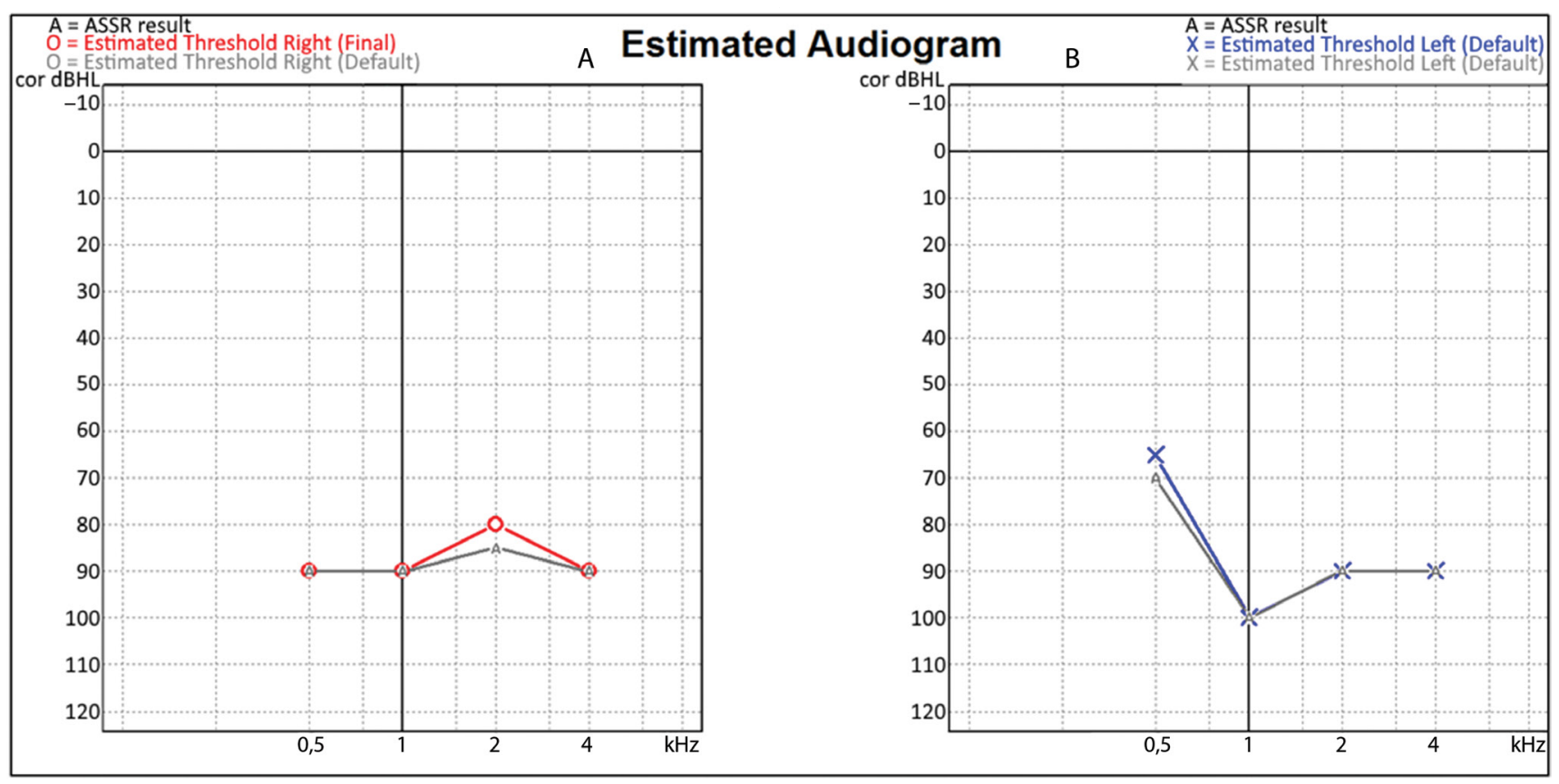

6. ábra

Preoperatív objektív hallásküszöbértékek jobb és bal oldalon. Auditoros steady-state válaszok (ASSRs) vizsgálata során az objektív hallásküszöböt, ezzel a residualis hallást mindkét oldalon nagy-súlyos fokban emelkedettnek mértük. A hallásküszöb a jobb oldalon (A) az objektív hallásküszöb $80-90$ dB corHL, míg a bal oldalon (B) 90-100 dB corHL mértékúnek bizonyult, bal oldalon 500 Hz-en relatíve megkímélt residualis hallással (corHL: hangintenzitás-korrekciós faktor figyelembevételével, mely tükrözi a beteg életkorát és a rögzítés körülményeit)

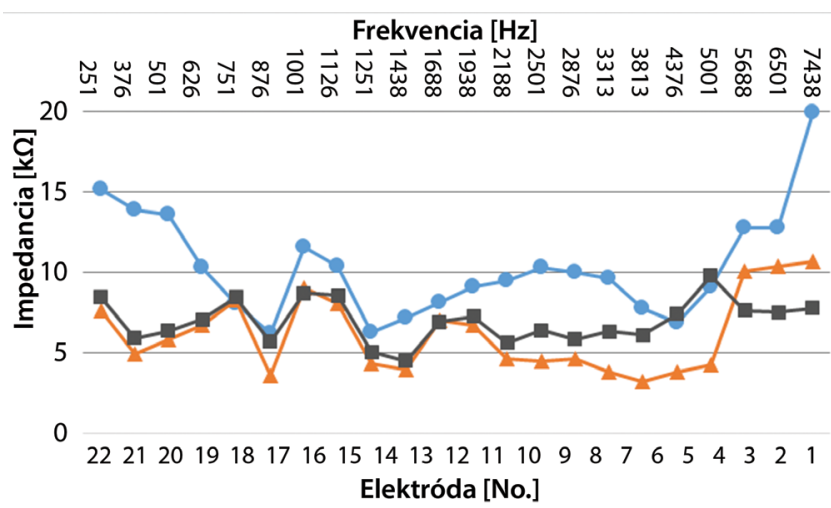

7. ábra

Posztoperatív elektródaimpedancia-változások. A posztoperatív hallásvizsgálatokkal egy időben elvégzett elektródánkénti impedanciamérések számos ingadozást mutatva, a 10-22. elektródatartományban már a 6. hónapban, míg az 1-9. elektródákon a 12. hónapban válnak relatíve stabillá, kiegyenlítetté. Ez az elektródasor megfelelő integrációjára, a belsőfül-homeosztázisnak a rendezettségére utalhat. A diagram felső tengelyén a különbözó elektródák frekvencialefedettség-átlaga került feltüntetésre

Jelölések: $-\bullet-=$ posztoperatív 4 . hét; $-\boldsymbol{\Delta}-=$ posztoperatív 6 hónap; - - = posztoperatív 12 . hónap

dése mindemellett lehetővé teszi, hogy a ganglion spirale szomszédos idegelemeit alacsonyabb áramintenzitással, kisebb felületen ingerelhessük.

Korai post mortem kadáverkísérletek során igazolták, hogy az interscalaris (azaz a scala tympaniból a scala vestibuliba történő) elektródadiszlokációhoz már 42-122 $\mathrm{mN}$ (átlagosan $88 \mathrm{mN}$ ) erő kifejtése is elegendő, mely- nek manuális érzékelhetősége kérdéses [41]. Nagy esetszámon ( $\mathrm{n}=100)$ végzett vizsgálatokkal kimutatták, hogy cochleostoma készítése során szignifikáns mértékben nőtt a valószínúsége, hogy az elektródasor a scala vestibuliban helyezkedjen el, ami a betegek beszédértésjavulásának elmaradásában is megnyilvánult [42].

Számos tanulmányban az intraoperatívan elvégzett electrocochleographiai mérések segítségével követhetőnek tartják az elektróda bevezetése során létrejövő traumát, végső soron a posztoperatív residualis hallás megőrzésének tényét $[12,43,44]$.

A posztoperatív időszakban esetünkben is mérhető volt a residualis hallás küszöbértékeinek fluktuációja. A funkcionális romlás hátterében az elektródasor megfelelő integrációja, a belsőfül-homeosztázisnak a rendeződése, végső soron egy adaptációs folyamat állhat. Az implantáció által facilitált neuroregeneráció ugyanakkor a hallásküszöb javulását eredményezheti.

Az EAS megvalósításához a külső hibrid beszédprocesszorok (akusztikus és elektromos) önmagukban nem elegendőek, az elektródasornak is atraumatikus profillal kell rendelkeznie, hogy a belső fül struktúráinak megőrzése révén lehetőség legyen a residualis akusztikai hallás hosszabb távú megőrzésére [45].

Esetünk jól demonstrálja, hogy minimálisan invazív technikát, valamint atraumatikus elektródasort alkalmazva a residualis hallás hosszabb távon megőrizhető. Az új típusú CI532 Slim Modiolar elektródasorral nyert kedvező tapasztalataink előrevetítik annak lehetőségét, hogy a cochlea minden régiójának szerkezeti és funkcionális 
épsége megőrizhető, ugyanakkor végleges megoldást nyújthat egy esetlegesen bekövetkező késői halláscsökkenés-progresszió kapcsán, amikor is elegendő csupán az implantátum pszichofizikai módszerekkel történő átprogramozása.

Eredményeink alapján, amennyiben a kezdeti tapasztalatoknak megfelelő biztonsággal és hatékonysággal őrizhető meg az akusztikai residualis hallás, úgy lényegesen kevesebb mütéti és altatási teher mellett leszünk képesek tartósan kiemelkedő hallásrehabilitációt biztosítani az EAS indikációjában is, ami jelentős életminőség-javulást, továbbá financiális tehercsökkenést eredményez a beteg és a társadalom számára egyaránt.

Emellett a residualis hallás hosszabb távú megőrzése kiemelkedő fontosságúnak bizonyulhat a későbbi regeneratív eljárások, gyógyszeres kezelések megvalósíthatósága kapcsán is $[46,47]$.

\section{Következtetés}

A cochlearis implantáció során alapvető szerep jut, a minimálinvazív technikák mellett, az individuális igényeket figyelembe vevő, hosszú távon is biztonságos hallásmegőrzést nyújtó elektródasorok alkalmazásának. Esetünk jól demonstrálja a Nucleus CI532 Slim Modiolar elektródaprofil hatékonyságát residualis akusztikai hallás esetében, ami előrevetíti az elektródasorok ezen generációjának EAS-rendszerek részeként történő alkalmazhatóságát, hosszabb távon biztosítva egy esetlegesen a jövőben megjelenő, sejtregeneráción alapuló új terápiás módszer alkalmazhatóságának alapját.

Anyagi támogatás: A közlemény megírása anyagi támogatásban nem részesült.

Szerzôi munkamegosztás: N. R.: Elektrofiziológiai mérések elvégzése, az ábrák megszerkesztése, a kézirat nyers változatának elkészítése. J. J. A.: Audiológiai leletek értékelése, a kézirat végleges szövegének megírása. D. B.: Elektrofiziológiai és audiológiai mérések elvégzése. P. Á.: A cochlearis impantációs kivizsgálás megszervezése, részvétel a mütét folyamatában. T. F.: Az elektrofiziológiai mérések értékelése, lektorálás. Sz. V.: A belső fül regenerációját vizsgáló kutatások értékelése, kéziratra adaptálása. J. J.: A kézirat lektorálása, publikációra való felkészítése. K. J. G.: Az elektrofiziológiai mérések, audiológiai vizsgálatok menetének beállítása, ellenőrzése, eredményeik értékelése, tudományos tanácsadás. R. L.: $\mathrm{Az}$ implantációs team vezetője, a cochlearis implantáció elvégzése, a beteg posztoperatív gondozása, a végleges kézirat lektorálása, a publikáció folyamatának nyomon követése, irányítása, lektorálás.

Érdekeltségek: A szerzőknek nincsenek érdekeltségeik.

\section{Irodalom}

[1] Reinfeldt S, Håkansson B, Taghavi H, et al. New developments in bone-conduction hearing implants: a review. Med Devices (Auckl). 2015; 8: 79-93.

[2] Katona G, Küstel M. Hearing improvement with implantable hearing aids in children. [Hallásjavítás implantálható hallókészülékekkel gyermekkorban.] Gyermekgyógyászat 2016; 67: 113118. [Hungarian]

[3] Posta B, Jarabin JA, Perényi Á, et al. Pediatric hearing rehabilitation with the Baha ${ }^{\circledR}$ Attract implant system. [Fiatalkori hallásrehabilitáció Baha ${ }^{\circledast}$ Attract implantátumrendszerrel.] Orv Hetil. 2017; 158: 304-310. [Hungarian]

[4] Eshraghi AA, Nazarian R, Telischi FF, et al. The cochlear im plant: historical aspects and future prospects. Anat Rec (Hoboken). 2012; 295: 1967-1980.

[5] Friedland DR, Runge-Samuelson C. Soft cochlear implantation: rationale for the surgical approach. Trends Amplif. 2009; 13: 124-138.

[6] Irving S, Gillespie L, Richardson R, et al. Electroacoustic stimulation: now and into the future. Biomed Res Int. 2014; 2014: 350504.

[7] Cohen NL. Cochlear implant soft surgery: fact or fantasy? Otolaryngol Head Neck Surg. 1997; 117: 214-216.

[8] Carlson ML, Driscoll CL, Gifford RH, et al. Implications of minimizing trauma during conventional cochlear implantation. Otol Neurotol. 2011; 32: 962-968.

[9] Adunka O, Unkelbach MH, Mack M, et al. Cochlear implantation via the round window membrane minimizes trauma to cochlear structures: a histologically controlled insertion study. Acta Otolaryngol. 2004; 124: 807-812.

[10] Richard C, Fayad JN, Doherty J, et al. Round window versus cochleostomy technique in cochlear implantation: histological findings. Otol Neurotol. 2012; 33: 1181-1187.

[11] Jiam NT, Limb CJ. The impact of round window vs cochleostomy surgical approaches on interscalar excursions in the cochlea: preliminary results from a flat-panel computed tomography study. World J Otorhinolaryngol Head Neck Surg. 2016; 2: 142-147.

[12] O'Connell BP, Hunter JB, Wanna GB. The importance of electrode location in cochlear implantation. Laryngoscope Investig Otolaryngol. 2016; 1: 169-174.

[13] Khater A, El-Anwar MW. Methods of hearing preservation during cochlear implantation. Int Arch Otorhinolaryngol. 2017; 21 : 297-301.

[14] Kiss JG, Jori J. Heat trauma in the surgery of the facial nerve. [Hitzetrauma bei der Chirurgie des Nervus Facialis. In: Zrunek EH, Fleischmajer R. (Hrsg.) Aktuelles in der Otorhinolaryngologie, Österreichischer HNO-Kongress, Graz, 1984.] Thieme Verlag, Stuttgart, 1985; pp. 242-244. [German]

[15] Koch RW, Ladak HM, Elfarnawany M, et al. Measuring cochlear duct length - a historical analysis of methods and results. J Otolaryngol Head Neck Surg. 2017; 46: 19

[16] Perényi Á, Nagy A, Kiss JG, et al. The role of image reconstructions in ear surgeries, in case of ear malformations. In: Bari F, Almási L. (eds.) [Képi rekonstrukciók szerepe fülmútétekben, fülfejlődési rendellenesség esetében. In: Bari F, Almási L. (szerk.) Orvosi Informatika 2014. A XXVII. Neumann Kollokvium konferencia-kiadványa.] Pannon Egyetem, Veszprém, 2014; pp. 127-130. [Hungarian]

[17] Karkas A, Champfleur NM, Uziel A, et al. Benefit of preoperative temporal bone CT for atraumatic cochlear implantation. Otol Neurotol. 2018; 39: el86-e194.

[18] Perényi Á, Bella Z, Baráth Z, et al. Role of cone-beam computed tomography in diagnostic otorhinolaryngological imaging. [A cone-beam komputertomográfia alkalmazása a fül-orr-gé- 
gészeti képalkotásban.] Orv Hetil. 2016; 157: 52-58. [Hungarian]

[19] Pillsbury HC 3rd, Dillon MT, Buchman CA, et al. Multicenter US clinical trial with an electric-acoustic stimulation (EAS) system in adults: final outcomes. Otol Neurotol. 2018; 39: 299305.

[20] Fayad JN, Makarem AO, Linthicum FH Jr. Histopathologic assessment of fibrosis and new bone formation in implanted human temporal bones using 3D reconstruction. Otolaryngol Head Neck Surg. 2009; 141: 247-252.

[21] Cuda D, Murri A. Cochlear implantation with the nucleus slim modiolar electrode (CI532): a preliminary experience. Eur Arch Otorhinolaryngol. 2017; 274: 4141-4148.

[22] Fraysse B, Macías ÁR, Sterkers O, et al. Residual hearing conservation and electroacoustic stimulation with the Nucleus 24 Contour Advance cochlear implant. Otol Neurotol. 2006; 27: 624633.

[23] Briggs RJ, Tykocinski M, Lazsig R, et al. Development and evaluation of the modiolar research array - multi-centre collaborative study in human temporal bones. Cochlear Implants Int. 2011; 12: 129-139.

[24] Lehnhardt, E. Intracochlear placement of cochlear implant electrodes in soft surgery technique. HNO 1993; 41: 356-359.

[25] Friedland DR, Runge-Samuelson C. Soft cochlear implantation: rationale for the surgical approach. Trends Amplif. 2009; 13: 124-138.

[26] von Ilberg CA, Baumann U, Kiefer J, et al. Electric-acoustic stimulation of the auditory system: a review of the first decade. Audiol Neurootol. 2011; 16(Suppl 2): 1-30.

[27] Gantz BJ, Turner C, Gfeller KE, et al. Preservation of hearing in cochlear implant surgery: advantages of combined electrical and acoustical speech processing. Laryngoscope 2005; 115: 796802 .

[28] Roland JT Jr, Zeitler DM, Jethanamest D, et al. Evaluation of the short hybrid electrode in human temporal bones. Otol Neurotol. 2008; 29: 482-488.

[29] Dunn CC, Perreau A, Gantz B, et al. Benefits of localization and speech perception with multiple noise sources in listeners with a short-electrode cochlear implant. J Am Acad Audiol. 2010; 21: $44-51$.

[30] Gifford RH, Dorman MF, Skarzynski H, et al. Cochlear implantation with hearing preservation yields significant benefit for speech recognition in complex listening environments. Ear Heart 2013; 34: 413-425.

[31] Gifford RH, Driscoll CL, Davis TJ, et al. A within-subject comparison of bimodal hearing, bilateral cochlear implantation, and bilateral cochlear implantation with bilateral hearing preservation: high-performing patients. Otol Neurotol. 2015; 36: 13311337.

[32] Gifford RH, Grantham DW, Sheffield SW, et al. Localization and interaural time difference (ITD) thresholds for cochlear implant recipients with preserved acoustic hearing in the implanted ear. Hear Res. 2014; 312: 28-37.

[33] Loiselle LH, Dorman MF, Yost WA, et al. Using ILD or ITD cues for sound source localization and speech understanding in a complex listening environment by listeners with bilateral and with hearing-preservation cochlear implants. J Speech Lang Hear Res. 2016; 59: 810-818.

[34] Loiselle LH, Dorman MF, Yost WA, et al. Sound source localization by hearing preservation patients with and without symmetrical low-frequency acoustic hearing. Audiol Neurootol. 2015; 20: 166-171.

[35] Skarzynski H, Lorens A. Partial deafness treatment. Cochlear Implants Int. 2010; 11(Suppl 1): 29-41.

[36] Sweeney AD, Hunter JB, Carlson ML, et al. Durability of hearing preservation after cochlear implantation with conventionallength electrodes and scala tympani insertion. Otolaryngol Head Neck Surg. 2016; 154: 907-913.

[37] Mittmann P, Ernst A, Todt I. Intracochlear pressure changes due to round window opening: a model experiment. Sci World J. 2014; 2014: 341075.

[38] Harmat K, Thurén G, Simon L, et al. Comparative evaluation of vertigo in patients after stapedotomy and stapedectomy. [Posztoperatív vertigo vizsgálata stapedotomián és stapedectomián átesett betegeknél.] Orv Hetil. 2017; 158: 1503-1511. [Hungarian]

[39] Banakis Hartl RM, Mattingly JK, Greene NT, et al. A preliminary investigation of the air-bone gap: changes in intracochlear sound pressure with air- and bone-conducted stimuli after cochlear implantation. Otol Neurotol. 2016; 37: 1291-1299.

[40] Chole RA, Hullar TE, Potts LG. Conductive component after cochlear implantation in patients with residual hearing conservation. Am J Audiol. 2014; 23: 359-364.

[41] Schuster D, Kratchman LB, Labadie RF. Characterization of intracochlear rupture forces in fresh human cadaveric cochleae. Otol Neurotol. 2015; 36: 657-661.

[42] Wanna GB, Noble JH, Carlson ML, et al. Impact of electrode design and surgical approach on scalar location and cochlear implant outcomes. Laryngoscope 2014; 124(Suppl 6): S1-S7.

[43] Koka K, Litvak LM. Feasibility of using electrocochleography for objective estimation of electro-acoustic interactions in cochlear implant recipients with residual hearing. Front Neurosci. 2017; 11: 337.

[44] Dalbert A, Pfiffner F, Hoesli M, et al. Assessment of cochlear function during cochlear implantation by extra- and intracochlear electrocochleography. Front Neurosci. 2018; 12: 18.

[45] Mahmoud AF, Massa ST, Douberly SL, et al. Safety, efficacy, and hearing preservation using an integrated electro-acoustic stimulation hearing system. Otol Neurotol. 2014; 35: 1421-1425.

[46] Plontke SK, Götze G, Rahne T, et al. Intracochlear drug delivery in combination with cochlear implants: Current aspects. HNO 2017; 65(Suppl 1): 19-28.

[47] Mittal R, Nguyen D, Patel AP, et al. Recent advancements in the regeneration of auditory hair cells and hearing restoration. Front Mol Neurosci. 2017; 10: 236.

(Jarabin János András dr., Szeged, Tisza Lajos krt. 111., 6725 e-mail: jarabin.janos.andras@med.u-szeged.hu) 